\title{
Editorial \\ Working to Supply the Demand: Recent Advances in the Science of Zoo Animal Welfare
}

\author{
Katherine A. Cronin (D)
}

check for updates

Citation: Cronin, K.A. Working to Supply the Demand: Recent Advances in the Science of Zoo Animal Welfare. J. Zool. Bot. Gard. 2021, 2, 349-350. https://doi.org/ $10.3390 /$ jzbg2030024

Received: 21 June 2021

Accepted: 24 June 2021

Published: 1 July 2021

Publisher's Note: MDPI stays neutral with regard to jurisdictional claims in published maps and institutional affiliations.

Copyright: (C) 2021 by the author. Licensee MDPI, Basel, Switzerland. This article is an open access article distributed under the terms and conditions of the Creative Commons Attribution (CC BY) license (https:// creativecommons.org/licenses/by/ $4.0 /)$.
Animal Welfare Science Program, Lincoln Park Zoo, Chicago, IL 60614, USA; kcronin@lpzoo.org

If animal welfare scientists were economists, we would be saying that the demand for knowledge is increasing faster than the supply. The World Association of Zoos and Aquariums (WAZA) has announced that all national and regional associations must have an animal welfare evaluation process in place by 2023 [1]. Regional zoo associations, such as the Association of Zoos and Aquariums (AZA), the British and Irish Association of Zoos and Aquariums (BIAZA), the European Zoo and Aquarium Association (EAZA), and the Zoo and Aquarium Association Australasia (ZAA) have begun requiring member organizations to conduct regular animal welfare assessments [2,3]. Some research on the public perception of zoos and aquariums reveal a lack of trust in zoos in aquariums to meet the emotional needs of animals in their care and to share information about animal welfare [4,5]. Therefore, the demand for welfare knowledge is high, both within the industry and from the general public.

The supply of welfare knowledge is lagging behind the demand. Certainly, there is an increase in information being published $[2,6]$ and applicable knowledge exists outside of the scientific literature as well. However, several systematic literature reviews $[2,6,7]$ have concluded that there is a need for more empirically derived information about how to measure and promote good welfare for many species in zoos and aquariums. Given that zoos and aquariums care for thousands of different species in a myriad of different environments, with varying management approaches, we are in need of a great deal of research to draw strong inferences about how to support good animal welfare.

In a modest attempt to fill the gap between need and knowledge about the welfare of animals in zoos and aquariums, the topic of this Special Issue is "Recent Advances in the Science of Zoo and Aquarium Animal Welfare." Contributors were especially encouraged to share science that could translate into practical applications in zoos and aquariums. In the 15 contributions to this Special Issue, we learn about how to assess welfare in typically understudied species, such as Nile crocodiles [8] and American toads [9]. We consider the shortcomings of some dominant approaches [10,11], the novel application of existing approaches [12,13], and the application of entirely new approaches $[14,15]$ to big questions in zoo and aquarium animal welfare. We also gain knowledge from established approaches applied to new welfare questions regarding effects of enrichment [16,17], seasonality [18], construction disturbances [19], cross-fostering [20], and the return of visitors to zoos postCOVID closures [21].

Some publications in this Special Issue can be applied to both zoo and aquarium populations [10-12,14]; however, contributions for this Special Issue all originated from research conducted at zoological institutions. This unfortunate lack of aquarium representation underscores the need for more research and dissemination on aquatic animal welfare.

This Special Issue supplies new knowledge that can be applied in our efforts to empirically evaluate and enhance the welfare of animals in zoos and aquariums. Although the gap between the demand for welfare science and the supply remains large, we have more knowledge than we did previously, and we should remain vigilant for opportunities to disseminate it and integrate it into practice. 
Acknowledgments: I thank all of the authors who contributed work to this Special Issue, and the reviewers and editors that contributed time and expertise to strengthening this collection.

Conflicts of Interest: The author declares no conflict of interest.

\section{References}

1. WAZA's Approach to Animal Welfare. Available online: https://www.waza.org/priorities/animal-welfare/our-approach-toanimal-welfare/ (accessed on 8 April 2021).

2. Binding, S.; Farmer, H.; Krusin, L.; Cronin, K.A. Status of animal welfare research in zoos and aquariums: Where are we, where to next? J. Zoo Aquar. Res. 2020, 8, 166-174. [CrossRef]

3. Warsaw, D.; Sayers, J. The influence of animal welfare accreditation programmes on zoo visitor perceptions of the welfare of zoo animals. J. Zoo Aquar. Res. 2020, 8, 188-193. [CrossRef]

4. Rank, S.J.; Voiklis, J.; Gupta, R.; Fraser, J.R.; Flinner, K. Understanding organizational trust of zoos and aquariums. In Understanding the Role of Trust and Credibility in Science Communication; Hunt, K.P., Ed.; Iowa State University: Ames, IA, USA, 2018.

5. Maynard, L. Media framing of zoos and aquaria: From conservation to animal rights. Environ. Commun. 2018, 12, 177-190. [CrossRef]

6. Rose, P.E.; Brereton, J.E.; Rowden, L.J.; Lemos de Figueiredo, R.; Riley, L.M. What's new at the zoo? An analysis of ten years of zoo-themed research output. Palgrave Commun. 2019, 5, 128. [CrossRef]

7. Melfi, V.A. There are big gaps in our knowledge, and thus approach, to zoo animal welfare: A case for evidence-based zoo animal management. Zoo Biol. 2009, 6, 574-588. [CrossRef] [PubMed]

8. Riley, A.; Terry, M.; Freeman, H.; Alba, A.C.; Soltis, J.; Leeds, A. Evaluating the effect of visitor presence on Nile crocodile (Crocodylus niloticus) behavior. J. Zool. Bot. Gard. 2021, 2, 115-129. [CrossRef]

9. Woody, S.M.; Santymire, R.S.; Cronin, K.A. Posture as a non-invasive indicator of arousal in American toads (Anaxyrus americanus). J. Zool. Bot. Gard. 2021, 2, 1-9. [CrossRef]

10. Watters, J.V.; Krebs, B.L.; Eschmann, C.L. Assessing animal welfare with behavior: Onward with caution. J. Zool. Bot. Gard. 2021, 2, 75-87. [CrossRef]

11. Wark, J.D.; Wierzal, N.K.; Cronin, K.A. Gaps in live inter-observer reliability testing of animal behavior: A retrospective analysis and path forward. J. Zool. Bot. Gard. 2021, 2, 207-221. [CrossRef]

12. Hopper, L.M. Leveraging social learning to enhance captive animal care and welfare. J. Zool. Bot. Gard. 2021, 2, 21-40. [CrossRef]

13. Finch, K.; Sach, F.; Fitzpatrick, M.; Rowden, L.J. Insights into activity of zoo housed Asian elephants (Elephas maximus) during periods of limited staff and visitor presence, a focus on resting behaviour. J. Zool. Bot. Gard. 2021, 2, 101-114. [CrossRef]

14. Schneider, S.; Dierkes, P.W. Localize animal sound events reliably (LASER): A new software for sound localization in zoos. J. Zool. Bot. Gard. 2021, 2, 146-163. [CrossRef]

15. Fuller, G.; Hamilton, J.; Allard, S. DNA damage as a potential non-invasive indicator of welfare: A preliminary study of zoo-housed grizzly bears (Ursus arctos horribilis). J. Zool. Bot. Gard. 2021, 2, 316-334. [CrossRef]

16. Laméris, D.W.; Verspeek, J.; Depoortere, A.; Plessers, L.; Salas, M. Effects of enclosure and environmental enrichment on the behaviour of ring-tailed lemurs (Lemur catta). J. Zool. Bot. Gard. 2021, 2, 164-173. [CrossRef]

17. Nash, R.; Johnston, H.; Robbins, A.; Descovich, K. The effect of enrichment filling and engagement time on regurgitation and reingestion behaviour in three zoo-housed orangutans. J. Zool. Bot. Gard. 2021, 2, 10-20. [CrossRef]

18. Fernandez, E.J.; Yoakum, E.; Andrews, N. Seasonal and daily activity of two zoo-housed grizzly bears (Ursus arctos horribilis). J. Zool. Bot. Gard. 2020, 1, 1-12. [CrossRef]

19. Williams, L.J.; Finch, K.; Agnew, R.; Holmes, L. Effects of nearby construction work on the behavior of Asiatic lions (Panthera leo persica). J. Zool. Bot. Gard. 2021, 2, 66-74. [CrossRef]

20. Kidd, P.; Rose, P. Influences of rearing environment on behaviour and welfare of captive Chilean flamingos: A case study on foster-reared and parent-reared birds. J. Zool. Bot. Gard. 2021, 2, 174-206. [CrossRef]

21. Williams, E.; Carter, A.; Rendle, J.; Ward, S.J. Impacts of COVID-19 on animals in zoos: A longitudinal multi-species analysis. J. Zool. Bot. Gard. 2021, 2, 130-145. [CrossRef] 